\title{
Studies on Qualitative and Quantitative Phytochemical Constituents of Moringa oleifera leaf Meal
}

\author{
A. Ajantha, C. Kathirvelan*, M. R. Purushothaman and P. Visha \\ Veterinary College and Research Institute, Tamil Nadu Veterinary and Animal Sciences \\ University, Namakkal - 637002 Tamil Nadu, India \\ *Corresponding author
}

\begin{tabular}{l} 
K e y w o r d s \\
Moringa oleifera \\
leaf meal, \\
phytochemical \\
constituents, \\
Extract, Alkaloids, \\
Poly phenols \\
\hline Article Info \\
\hline $\begin{array}{l}\text { Accepted: } \\
\text { 20 May } 2020 \\
\text { Available Online: } \\
\text { 10 June } 2020\end{array}$ \\
\hline
\end{tabular}

\section{Keywords}

Moringa oleifera leaf meal, phytochemical constituents, Poly phenols

Article Info

Accepted: Available Online 10 June 2020
Plants have served animals and humans as a natural source for therapies from ancient times, amongst them medicinal herbs have gain attention because of its wide use and less side effects. In the recent years plant research has increased throughout the world and a huge amount of evidences have been collected to show immense potential of medicinal plants used in various traditional systems, thus in the present investigation the phytochemical analysis of Moringa oleifera leaf meal was carried out as these plants have been proved to be one of the important nutritional and medicinal plant. The phytochemical analysis was carried out for the Moringa oleifera leaf meal extracted with aqueous and alcoholic solvents. The qualitative showed that presence of flavonoids, tannins, total phenols, saponins, and alkaloids were mainly seen in aqueous and alcoholic extract of leaf meal. In quantitative analysis showed that the level of flavonoids, tannins, total phenols, saponin and alkaloids in aqueous extract of Moringa oleifera leaf meal were 3.60, $1.25,2.02,0.59$ and 1.12 per cent respectively. The presences of high amount of phytochemical constituents suggest that the Moringa oleifera plant has higher medicinal value and can be extensively studied to extract the natural compounds which are beneficial to animals and humans.

\section{Introduction}

Medicinal plants and herbs are great importance to the health of the animals and also humans. Plants are composed of complex mixtures of secondary metabolites, which exhibit therapeutic effect. These are called phytochemicals and include alkaloids, glycosides, terpenoids and phenols. Moringa oleifera referred as 'Drum stick tree' belongs to the family of Moringaceae is considered as a native plant of India, Pakistan and Africa (Zvinorova et al., 2015). It can survive in harsh climatic condition including destitute soil without being much affected by drought. Every part of the Moringa oleifera tree, from the roots to the leaves has beneficial properties. The Moringa oleifera leaf contains 
various phytochemical constituents, crude protein, amino acids, fatty acids, vitamins, minerals and other nutrients (Fahey, 2005). Many reports described Moringa oleifera as having highly potent antioxidant, antibacterial, hypolipidimic, antiinflammatory and hepatoprotective activity (Divya et al., 2015). The leaf extracts were found to regulate the serum cholesterol level in rats due to its hypocholesterolaemic activity (Ghasi et al., 2000). The leaves, flowers and pods are used as good sources of protein, vitamins $\mathrm{A}, \mathrm{B}, \mathrm{C}$, and minerals $\mathrm{Ca}, \mathrm{K}$, $\mathrm{Fe}, \mathrm{Zn}$ and amino acids. This makes the plant a natural source of chemical compounds with medicinal value and making it a plant with greater commercial value. In order to contribute to growing body of knowledge on this subject, the present study analysed the phytochemical constituents of aqueous and alcoholic extract of Moringa oleifera leaf meal.

\section{Materials and Methods}

\section{Collection of sample}

Fresh and healthy Moringa oleifera leaves were collected from Namakkal district. The plant was authenticated as Moringa oleifera Lam by Botanical Survey of India, Coimbatore. Stem and branches were cut from Moringa trees and spread out under the shade to dry at room temperature for 7 days. The leaves were removed manually and ground into fine powder and used for extraction.

\section{Preparation of Moringa oleifera leaf extract}

Ten per cent aqueous and alcoholic extracts of Moringa oleifera leaf were prepared by adding ten gram of dry powder in hundred $\mathrm{mL}$ of distilled water and $70 \%$ alcohol respectively. It was kept in a rotatory shaker for $48 \mathrm{hrs}$, filtered and then incubated at $37^{\circ} \mathrm{C}$ for $48 \mathrm{hrs}$ to evaporate the solvent. The dried extract was removed and stored in airtight container and used for further evaluation.

\section{Qualitative phytochemical analysis}

Qualitative phytochemical analysis of aqueous and alcoholic extracts of Moringa oleifera leaf was carried out as per method of Harborne, (1998).

\section{Detection of flavonoids}

To $2.0 \mathrm{~mL}$ of aqueous and alcoholic extracts, few drops of sodium hydroxide solution were added. Formation of intense yellow color, which became colorless on addition of dilute $\mathrm{HCl}$ indicated the presence of flavonoids.

\section{Detection of tannins}

To $2.0 \mathrm{~mL}$ of aqueous and alcoholic extracts, 3 drops of $1 \%$ ferric chloride was added. Appearance of blue green color indicated the presence of tannins.

\section{Detection of total phenols}

Two $\mathrm{mL}$ of aqueous and alcoholic extracts were diluted with $2 \mathrm{~mL}$ of $10 \%$ ferric chloride. Formation of bluish color indicated the presence of phenols.

\section{Detection of saponins}

Two $\mathrm{mL}$ of aqueous and alcoholic extracts were diluted with $10 \mathrm{~mL}$ of distilled water and mixed for $15 \mathrm{~min}$. Formation of layers of foam which remained for $10 \mathrm{~min}$ indicated the presence of saponins.

\section{Detection of alkaloids}

To 2.0mL of aqueous and alcoholic extracts, $2 \mathrm{~mL}$ of picric acid (Hager's reagent) was added. Formation of an orange or yellow 
color precipitate indicated the presence of alkaloids.

\section{Detection of phlobatannin}

To $2.0 \mathrm{~mL}$ of aqueous and alcoholic extracts, $1 \mathrm{~mL}$ of dilute HCL solution was added. Appearance of red precipitate indicated the presence of phlobatannins.

\section{Detection of hydrolysable tannin}

To $2.0 \mathrm{~mL}$ of aqueous and alcoholic extracts, $2 \mathrm{~mL}$ of ammonia solution was added. Formation of emulsion indicated the presence of hydrolysable tannin.

\section{Detection of terpenoids}

To $2.0 \mathrm{~mL}$ of aqueous and alcoholic extracts, an equal amount of chloroform was added followed by addition of $2 \mathrm{~mL}$ of concentrated $\mathrm{H}_{2} \mathrm{SO}_{4}$ along the sides of the test tube. Appearance of a brown color ring at the junction of two liquids indicated the presence of terpenoids.

\section{Detection of glycosides}

To $2.0 \mathrm{~mL}$ of aqueous and alcoholic extracts, $2 \mathrm{~mL}$ of dilute $\mathrm{H}_{2} \mathrm{SO}_{4}$ was added and heated at $50{ }^{\circ} \mathrm{C}$ for $2 \mathrm{~min}$. Then $1 \mathrm{~mL}$ of $10 \% \mathrm{NAOH}$ was added and $5 \mathrm{~mL}$ each of Fehling's solution A and B were added. Appearance of brick red precipitate indicated the presence of glycosides.

\section{Detection of cardiac glycosides}

To $2.0 \mathrm{~mL}$ of aqueous and alcoholic extracts, an equal amount of glacial acetic acid was added. Then, one drop of $10 \%$ ferric chloride and $2 \mathrm{~mL}$ of concentrated $\mathrm{H}_{2} \mathrm{SO}_{4}$ were added. Formation of three layers of colors like upper green, middle brown and lower violet indicated the presence of cardiac glycosides.

\section{Detection of Volatile oil}

To $2.0 \mathrm{~mL}$ of aqueous and alcoholic extracts, $0.1 \mathrm{~mL}$ of $\mathrm{NaOH}$ and a small amount of dilute $\mathrm{HCl}$ were added. Formation of white precipitate indicated the presence of Volatile oils.

\section{Quantitative phytochemical analysis}

This analysis was carried to determine the amount or concentration of the phytochemical constituents present in the aqueous extract of Moringa oleifera leaf.

\section{Flavonoids}

Flavonoids in plant extracts were determined by aluminium chloride colorimetric method (Chang et al., 2002). About $0.25 \mathrm{ml}$ of extract $(10 \mathrm{mg} / \mathrm{ml})$ was mixed with $0.75 \mathrm{ml}$ of ethanol, $0.05 \mathrm{ml}$ of 10 per cent aluminium chloride, $0.02 \mathrm{ml}$ of $1 \mathrm{M}$ potassium acetate and $1.4 \mathrm{ml}$ of distilled water. The reaction mixture was incubated at $37^{\circ} \mathrm{C}$ for 30 minutes. The absorbance of the mixture was measured at $415 \mathrm{~nm}$ using UV- VIS spectrophotometer.

\section{Tannins}

Tannin content was estimated as per the method of Pearson, (1976). About $1.0 \mathrm{~g}$ of the sample was dispersed in $10 \mathrm{ml}$ distilled water and agitated. This was left to stand for $30 \mathrm{~min}$ at room temperature and shaken every $5 \mathrm{~min}$. After $30 \mathrm{~min}$, it was centrifuged and the extract gotten. About $2.5 \mathrm{ml}$ of the supernatant extract was dispensed into a separate $50 \mathrm{ml}$ volumetric flask. Similarly, 2.5 $\mathrm{ml}$ of standard tannic acid was dispensed into a separate $50 \mathrm{ml}$ flask. The absorbance was measured at $250 \mathrm{~nm}$.

\section{Total phenols}

Total phenol was estimated as per the method of Makkar et al., (1993). Aqueous extract of 
MOLM at the rate of $0.1 \mathrm{mg} / \mathrm{ml}$ was mixed with $0.5 \mathrm{ml}$ of Folin-Ciocalteu phenol reagent (1:1 dilution with distilled water) and $2.5 \mathrm{ml}$ of 20 per cent sodium carbonate solution. The reaction mixture was allowed to stand for 40 minutes and the absorbance was measured at $725 \mathrm{~nm}$ using UV-VIS spectrophotometer.

\section{Saponin}

Saponin content was estimated as per the method of Amin et al., (2016). About $2 \mathrm{~g}$ of dried plant sample was dissolved in $50 \mathrm{ml}$ of petroleum ether. The suspension was heated over a hot water bath at $55^{\circ} \mathrm{C}$ for $1 \mathrm{hr}$ with continuous stirring. The mixture was filtered and the residue was re-extracted in $50 \mathrm{ml}$ of methanol.

The combined filtrates were reduced to $10 \mathrm{ml}$ by placing over water bath at about $90^{\circ} \mathrm{C}$. The concentrate was transferred into a $250 \mathrm{ml}$ separating funnel and acetone was added slowly and shaken well. The aqueous layer was recovered and the purification process was repeated. The remaining solution which contains saponin was heated in a water bath and the sample was dried in oven and weighed.

\section{Alkaloids}

The quantity of alkaloids was estimated as per the method of Harborne (1973). About $1 \mathrm{~g}$ of powered sample was mixed with $40 \mathrm{ml}$ of $10 \%$ acetic acid and allowed to stand for 4 hrs. It was filtered and concentrated on water bath to one fourth of its original volume then concentrated ammonium hydroxide was added drop by drop to the extracts until the precipitation was completed. The whole solution was allowed to settle and the precipitate was collected and washed with dilute ammonium hydroxide and then filtered. The residue is the alkaloid, which was dried and weighed.

\section{Results and Discussion}

\section{Qualitative analysis of Moringa oleifera leaf meal}

Qualitative phytochemical constituents of aqueous and alcoholic extracts of Moringa oleifera leaf meal are present in the Table 1.

Qualitative analysis showed that flavonoids, tannin, total phenols, saponin, alkaloids and phlobatannin were present in both aqueous and alcoholic extracts of Moringa oleifera leaf meal. However hydrolysable tannin and terpenoid were present in aqueous extracts of Moringa oleifera leaf meal. Similarly, the presence of tannins, flavonoids, saponins, alkaloids, phenols, glucoside in aquous extract of Moringa oleifera leaf meal was observed by Bamishaiye et al., (2011), Ajayi and Fadeyi, (2015). Dzotam et al, (2016) reported that presence of alkaloids, polyphenols, flavonoids, tannins, terpenoids, saponins, coumarins in methanolic extract of Moringa oleifra leaf meal.

\section{Quantitative analysis of Moringa oleifera leaf meal}

Quantitative phytochemical constituents of aqueous extracts of Moringa oleifera leaf meal are present in the Table 2. The level of flavonoids, tannins, total phenols, saponin and alkaloids in aqueous extract of Moringa oleifera leaf meal were 3.60, 1.25, 2.02, 0.59 and 1.12 per cent respectively.

The levels of flavonoids, tannins, total phenols and alkaloids were comparable to the earlier reports (Moyo et al., 2011; Alikwe and Omotosho, 2013; Kathryn, 2014; Ajayi and Fadeyi, 2015 and Kavoi et al., 2016) and lower level of saponin was reported by (Ogbe and Affiku, 2011; Aye and Adegun, 2013; Kavoi et al., 2016). The medicinal plants are usually linked with the presence of 
phytochemicals otherwise called secondary metabolites and these differ from one plant to another, accounting in part for the difference in pharmacological effects of medicinal plants. Flavonoids are potent antioxidant activity and revealed that ability to scavenge hydroxyl radicals, superoxide anions and lipid peroxyl radicals this may be important function of flavonoids (Bamishaiye et al., 2011). Tannins are proved haemostatic, widely used as mouthwashes, eyewashes and also treat rectal disorders. Total phenols are strong antioxidants which prevent oxidative damage to biomolecules such as DNA, lipids and proteins which play a role in chronic diseases (Hollman, 2001). Saponin has possessed cholesterol lower property and stimulation of immune system. Alkaloids have nitrogen containing compound, commonly found to have antimicrobial property due to their ability to intercalate with DNA of the microorganisms (Kasolo et al., 2010). In general, Moringa oleifera leaf meal has possess lot of medicinal property might be due to the presence of these phytochemical constituents in Moringa oleifera leaf meal.

Table.1 Qualitative phytochemical constituents of aqueous and alcoholic extracts of Moringa oleifera leaf meal

\begin{tabular}{|l|c|c|}
\hline Phytochemical constituents & Aqueous extract & Alcoholic extracts \\
\hline Flavonoids & ++ & + \\
\hline Tannin & + & + \\
\hline Total phenols & ++ & ++ \\
\hline Saponin & + & + \\
\hline Alkaloids & ++ & ++ \\
\hline Terpenoid & + & - \\
\hline Phylobatannin & + & + \\
\hline Hydrolysable tannin & - & + \\
\hline Volatile oil & - & - \\
\hline Glycosides & - & - \\
\hline Cardiac glycosides & - & - \\
\hline
\end{tabular}

Table.2 Quantitative phytochemical constituents of aqueous extracts of Moringa oleifera leaf meal

\begin{tabular}{|l|c|}
\hline \multicolumn{1}{|c|}{ Phytochemical constituents } & Composition (\%) \\
\hline Flavonoids & 3.61 \\
\hline Tannins & 1.25 \\
\hline Total phenols & 2.02 \\
\hline Saponins & 0.59 \\
\hline Alkaloids & 1.12 \\
\hline
\end{tabular}

Each value is a mean of two observations

In conclusion, the results revealed that Moringa oleifera leaf meal has potent antioxidant, antimicrobial, hypocholesterolaemic and growth promoting properties due to the presence of these phytochemical constituents. The result of this study indicates Moringa oleifera leaf meal contains presence of valuable phytochemical 
constituents that may offer chemo protective and medicinal value to animals. Viable effects detectable through biological evaluation of animals are necessary to enhance the acceptability and commercialization of this plant.

\section{Acknowledgements}

The authors are grateful to the Dean, Veterinary College and Research Institute, Namakkal and Tamil Nadu Veterinary and Animal Sciences University, Chennai for providing the necessary facilities for carrying out this research work. This is part of M.V.Sc research work.

\section{References}

Ajayi AO and Fadeyi TE. Antimicrobial activities and phytochemical analysis of Moringa oleifera leaves on Staphylococus aureus and Streptococcus Species. Am. J. Phytomed. Clin. Ther., 2015; 3(10): 643-653.

Alikwe PCN and Omotosho MS. An evaluation of the proximate and phytochemical composition of Moringa oleifera leaf meal as potential feedstuff for non- ruminant Livestock. Agrosearch., 2013; 13(1): 17-27.

Amin MM, Kajal Parihar, Uzma Tabasum and Ekata Kumari. Estimation of alkaloid, saponin and flavonoid, content in various extracts of Crocus sativa. J. Med. Plants. Stud., 2016; 4(5): 171-174.

Aye PA and Adegun MK. Chemical Composition and some functional properties of Moringa, Leucaena and Gliricidia leaf meals. Agric. Biol. J. N. Am., 2013; 4(1): 71-77.

Bamishaiye EI, Olayemi FF, Awagu EF and Bamshaiye OM. Proximate and Phytochemical Composition of Moringa oleifera Leaves at Three Stages of
Maturation. Adv. J. Food Sci. Technol., 2011; 3(4): 233-237.

Chang C, Yang M, Wen $\mathrm{H}$ and Chern J. Estimation of total flavonoid content in propolis by two complementary colorimetric methods. J. food dr. Anal., 2002; 10: 178-182.

Divya, Biswas A, Mandal AB, Praveen KT, Pramod KT and Chendra D. Effect of feeding Moringa (Moringa oleifera) leaves on immunity, carcass traits and keeping quality of meat of broiler chickens. Indian. J. Poult. Sci., 2015; 50(3): 300-304.

Dzotam JK, Touani FK and Kuete V. Antibacterial and antibiotic modifying activities of three food palnts (Xanthosoma mafaffa Lam., Moringa oleifera (L.) Schott and Passiflora edulis Sims) against multidrug resistant (MDR) gram-negative bacteria. $B M C$ Complement. Altern. Med., 2016; 16(2): 1-8.

Fahey J. Moringa oleifera: A review of the medical evidence for its nutritional, therapeutic, and prophylactic properties, Trees. Life. J., 2005; 1:1-33.

Ghasi S, Nwobodo E and Ofili JO. Hypocholesterolemic effects of crude extract of leaf of Moringa oleifera Lam in high fat diet fed wistar rats. $J$. EthnoPharmacol., 2000; 69(1): 21-25.

Harborne AJ. Phytochemical methods: A guide to modern techniques of plant analysis. Springer Sci. Business Media. 1998.

Harborne J. Phytochemical Methods. Chapman and Hall, Ltd London: 1973;49-188.

Hollman PC. Evidence for health benefits of plant phenols; Local or synthetic effects. J. Sci. Food. Agric., 2001; 81: 842-852.

Kasolo JN, Gabriel S, Bimenya LO, Joseph O and Ogwal-Okeng JW. Phytochemicals and uses of Moringa oleifera leaves in 
Ugandan rural communities. J. Med. Plants. Res., 2010; 4(9): 753-757.

Kathryn A. The Nutrient Content of Moringa oleifera Leaves. Edu. Concern. Hunger. Org., 2014; 1-6.

Kavoi BM, Gakuya DW, Mbugua PN and Kiama SG. Effects of dietary Moringa oleifera leaf meal supplementation on chicken intestinal structure and growth performance. J. Morphol. Sci., 2016; 33(4): 186-192.

Makkar HPS, Blummel M, Borowy NK and Becker K. Gravimetric determination of tannins and their correlations with chemical and protein precipitation methods. J. Sci. Agric., 1993; 61: 161165.

Moyo B, Masika PJ, Hugo A and Muchenje V. Nutritional characterization of Moringa (Moringa oleifera Lam) leaves. Afr. J. Biotechol., 2011; 10 (60): 2925-2933.

Ogbe AO and Affiku, JP. Proximate study, mineral and anti-nutrient composition of Moringa oleifera leaves harvested from Lafia, Nigeria: potential benefits in poultry nutrition and health. $J$. Microbiol. Biotechnol. Food.Sci., 2011; 1: 296-308.

Pearson D. Chemical Analysis of Foods. Edn 7, Edinburgh Churchill, Livingstone, 1976. Zvinorova PI, Lekhanya L, Erlwanger K, Chivandi E. Dietary effects of Moringa oleifera leaf powder on growth, gastrointestinal morphometery and blood and liver metabolites in Sprague Dawley rats. $J$. Anim physiol. Anim nutr., 2015; 99, 2128.

\section{How to cite this article:}

Ajantha, A., C. Kathirvelan, M. R. Purushothaman and Visha, P. 2020. Studies on Qualitative and Quantitative Phytochemical Constituents of Moringa oleifera leaf Meal. Int.J.Curr.Microbiol.App.Sci. 9(06): 4195-4201. doi: https://doi.org/10.20546/ijcmas.2020.906.491 